\title{
CRIME AND CUSTOM IN CORPORATE SOCIETY: A CULTURAL PERSPECTIVE ON CORPORATE MISCONDUCT
}

\author{
JOHN M.CONLEY*AND WILLIAM M. O'BARR**
}

\begin{abstract}
I
INTRODUCTION

We draw our title from Crime and Custom in Savage Society, B ronislaw Malinowski's 1926 study of law, deviance, and social control in the Trobriand Islands of the southwest Pacific. ${ }^{1}$ M alinowski, an Englishman born of Polish parents, was one of the inventors of modern ethnography, the anthropological practice of living among the people to be studied, participating in their culture, and trying to see the world though their eyes. (A s with so many other inventions, this one had an accidental component: Malinowski's sojourn in the Trobriands was essentially a form of internment as a suspect alien during World War $\left.I^{2}{ }^{2}\right)$ A Ithough Malinowski's theoretical stance ${ }^{3}$ and reporting style $e^{4}$ now seem almost comically dated, Crime and Custom remains significant as the earliest effort to argue that societies lacking such Western trappings as judges, courts, and police can still have "law" in a meaningful sense.

$M$ alinowski lacked a sense of culture that would be congenial to modern anthropologists and sociologists-indeed, as far as we can tell, the word "culture" does not appear in Crime and Custom-but he was, nonetheless, the first to take a cultural approach to law. The phenomenon that we in the West call "law" is that set of cultural beliefs and practices that establishes norms for conduct, defines the limits of tolerable deviance, and decides how to deal with those who cross the line. N ot only need law not take on the institutional form

Copyright (c) 1997 by L aw and Contemporary Problems

This article is also available at http://www.law.duke.edu/journals/lcp.

* Professor of L aw, U niversity of N orth Carolina, Chapel H ill.

** Professor of Cultural A nthropology, D uke U niversity.

1. The Trobriands lie just off the eastern tip of $\mathrm{New}$ G uinea and are now part of the nation of Papua N ew G uinea.

2. For a short biography of M alinowski, see the scholarly obituary, A udrey I. Richards, B ronislaw K aspar M alinowski, 43 M A N 1 (1943).

3. Malinowski was one of the founders of the functionalist school of anthropology, most prominently associated with B ritish social anthropologists of the 1940 s and ' 50 s. See J ohn M. Conley \& William M. O'Barr, L egal A nthropology Comes Home: A B rief History of the E thnographic Study of L aw, 27 L OY . L.A. L. REV . 41, 43-44 (1993).

4. The Introduction to Crime and Custom, for example, is full of references to such things as "the mental processes of savages," "morally improving the native," and "primitive legality." B RONISLAW MALINOWSKI, CRIME AND CUSTOM IN SA VA Ge SOCIETY 1-5 (1926).
\end{abstract}


familiar to the West, it need not have any institutional manifestation at all. On the contrary, as M alinowski demonstrated, the job of law can get done in a surprising variety of ways, often through the use of resources drawn from such unexpected domains as religion, economics, and even kinship.

Malinowski's original audience was the first generation of field ethnographers, those early twentieth century anthropologists and sociologists who fanned out across the globe to explain the exotic "other" to the Western intellectual world. ${ }^{5}$ But his message has also had meaning for people like us who study law in Western societies. We take three principal points away from Crime and Custom. The first is the power of the ethnographic method. Simply put, to understand how any institution works, one must watch it in action on a daily basis rather then simply examining the pronouncements of those who purport to be in authority. The second point is the need to see legal problems as cultural problems. In Western industrial societies, law is a special-purpose institution, its processes largely walled off from the society it purports to serve. (Think of the recent high-profile cases heard by jurors who were selected because they had no idea what was going on in the world.) The anthropological perspective reminds us that we can benefit from putting law back into its cultural context, emphasizing the very connection between law and society that formal legal proceedings often seek to suppress. The third point is that Malinowski's work reminds us that law is itself a cultural institution. The practice of law is a human practice, and human beings always practice in cultural ways. There is, thus, something to be learned from looking at law and legal processes in the same way as we might look at families or religion or social organizations.

We turn next to the question of how anthropologists can contribute to the study of corporate misconduct. The answer is quite simple: A nthropologists can help to describe what corporate misconduct is and how it can be understood in cultural terms. A t first glance, this might seem a trivial contribution. O ne might argue that judges and lawyers know perfectly well what corporate misconduct is and need to move on to questions of punishment and deterrence. But how much do we really know about the nature of the phenomenon?

In elemental form, a corporation is a set of papers given some sort of incorporeal life by a secretary of state's seal. When a corporation assumes concrete form-when it acquires the capacity for conduct or misconduct-it does so only through the activities of a group of people. To say that the corporation has engaged in misconduct is to say that some of the people have misbehaved in ways that the law chooses to attribute to the corporate entity. But what kinds of individual misconduct should be thus attributed? U nder what circumstances are corporate people most likely to misbehave? What kinds of incentives or disincentives can the law provide to minimize such behavior in the future? The conventional legal answers to such questions are premised on some assumptions about individual action, the nature of corporate organizations, and the way responsibility is shared by individuals and groups. A $n$ anthropological an-

5. See Conley \& O 'B arr, supra note 3 , at $45-46$. 
swer to any of these questions requires an appreciation of the corporation as a cultural milieu, a setting where a group of self-identifying people with certain shared beliefs engage in a set of distinctive and mutually intelligible practices.

We have in mind stepping back from the usual assumptions and treating the corporation as if it were exotic, a part of some unfamiliar culture rather than our own. A s anthropologists, we treat our own conventional understandings not as resources but as blinders that need to be removed. When we apply the anthropological method to our own society, our objective is to "defamiliarize" the familiar, to see our society as M alinowski saw the Trobriands. In analyzing elements of our own culture, we attempt to put aside preconceptions and received wisdom and to force ourselves to start from scratch, as if we had just landed on a far-off island.

The purpose of the paper is to take an anthropological perspective on three widely publicized cases of alleged corporate misconduct: a study showing that car dealers discriminate on the basis of the race and gender of their customers, the A rcher Daniels Midland saga, and the manipulation of incriminating documentary evidence by the tobacco companies. In each case, we will analyze the cultural context that made such behavior possible and discuss the law's capacity to deter similar conduct in the future.

THE CASES

The three case studies-car dealer discrimination, A rcher D aniels M idland, and the tobacco documents- present three strikingly different models of corporate misconduct. In the auto dealer case, the behavior that we label "corporate" appears to be little more than the aggregation of numerous individual actions whose motivation may have little if anything to do with corporate culture. In the A rcher $\mathrm{D}$ aniels $\mathrm{M}$ idland case, by contrast, the acts of misconduct appear to have been enabled, if not driven, by the core values of the corporate culture. Finally, the tobacco case reflects a complex interaction between corporate values and the values of an outside institution, ironically, the law. A s we shall see, the three cases present some of the essential issues in an ongoing debate in the social sciences about the fundamental nature of culture.

\section{A . Car D ealer D iscrimination}

In a $1991 \mathrm{H}$ arvard Law Review article, law professor Ian A yres (then at Northwestern, now at $Y$ ale) presented the results of an empirical study of gender and race discrimination in retail car sale negotiations. ${ }^{6} U$ sing a method developed to study housing discrimination, A yres dispatched a group of "testers" to shop for cars in the Chicago area. The pairs of testers (one member of each of the pair was a white male, the other was a black male, black female, or white

6. See Ian A yres, Fair D riving: G ender and Race Discrimination in Retail Car Negotiations, 104 HARV. L. REV. 817 (1991). 
female) approached each of ninety dealerships and followed a bargaining script in which they negotiated only over the issue of price. A II testers were of similar age and wore similar clothing. They claimed similar levels of education and employment as well as residence in an upperclass neighborhood, and all asserted that they could pay cash for the car. O n average, the dealers' final offers to the white male testers reflected a $\$ 362$ dealer profit; the comparable figures for the white females, black males, and black females were $\$ 504, \$ 783$, and an astonishing $\$ 1,237$. $^{7}$ Similar disparities showed up in other measures of bargaining success. In addition, A yres identified several types of "non-price discrimination" by the dealer sales personnel, including "steering" testers to salespersons of their own gender and race, ${ }^{8}$ disparities in the questions they asked the testers, ${ }^{9}$ and a disproportionate unwillingness to disclose cost data to A frican A merican testers. ${ }^{10} \mathrm{~A} n$ interesting subsidiary finding was that testers often fared worse with salespeople of their own race and gender. ${ }^{11}$

A fter demonstrating the reality of disparate treatment of women and A frican A mericans, A yres explored a number of possible explanatory theories. They fall into two general categories: animus-based theories, which "posit that a certain group is treated differently because that group is disliked or hated," 12 and statistical theories, which "predict that disparate treatment will stem not from distaste for particular consumer groups but rather from a seller's desire to maximize profits." 13 In support of animus theories, A yres notes that the testers recorded many instances of blatantly sexist and racist language by dealership personnel. He concludes, however, that "animus theories do not appear to explain the magnitude of discrimination," and turns his attention to a "revenuebased" explanation. ${ }^{14}$ U nder this theory, "disparate treatment may stem from the fact that dealers are using race and gender as the basis from which to draw inferences about willingness to pay and, in particular, from which to draw inferences regarding the amount of potential or actual dealer competition for black and female customers." 15

If the revenue-based analysis is valid, one might plausibly accuse the salespeople of committing sociology. Since they work on commission, their primary economic motive is always to get the highest possible price for the car (their employers' interests coincide with their own, of course). To maximize their economic return in individual transactions, they seek information about their bargaining partners, the customers. When they do not know the customers per-

7. See id. at 828. In a subsequent study, A yres reaffirmed the original findings, except that the order of the black males and black females was reversed. I an A yres, Further $E$ vidence of D iscrimination in N ew Car N egotiations and E stimates of I ts Cause, 94 M ICH. L. R E V. 109 (1995).

8. See A yres, supra note 6 , at 833 .

9. See id. at 834 .

10. Seeid. at 835 .

11. See id. at 840

12. Seeid. at 841 .

13. Seeid. at 842 .

14. See id. at 846 .

15. Seeid. at 848 . 
sonally (as was the case with A yres's testers, and is presumably the case most of the time), they draw inferences from the available cues- things like dress, residence, ability to pay, and, it appears, race and gender.

In interpreting such cues, the individual salespeople will inevitably fall back on widely shared beliefs and understandings - in other words, on culture. Shared cultural beliefs provide the resources for interpreting such cues as "well-dressed," "A frican A merican," or "female." ${ }^{16}$ These resources, culturally-derived sociological generalizations, are usually a mixture of truths and falsehoods. ${ }^{17}$ E ven when specific pieces of cultural information are true, they may lead to social consequences we would prefer to avoid. (For example, cab drivers may be right that picking up A frican A merican males with certain clothing styles will increase their exposure to crime. B ut the outcome is still regrettable.) Significantly, each act of interpretation by an auto salesperson simultaneously reflects and reinforces the cultural beliefs on which it is premised. ${ }^{18}$ The reflection part of the equation is obvious: When a salesperson takes an aggressive position in bargaining with an A frican A merican woman, for example, he is acting on a cultural stereotype about the weakness and vulnerability of that class of person. B ut in the manner of a self-fulfilling prophecy, the salesperson's conduct also adds to the strength of the stereotype.

A yres's findings and interpretations harmonize nicely with contemporary cultural theory. Earlier in this century, culture was widely viewed as a real and robust entity; what a leading early-twentieth-century anthropologist famously called "the superorganic." ${ }^{19}$ From this perspective, the set of shared beliefs and practices that comprise culture can take on a life of its own, ultimately dictating the day-to-day behavioral choices of its constituents. In opposition to this perspective, there emerged a theory that culture is nothing more than a statistical statement, or epiphenomenon..$^{20}$ In this view, the thing we call culture is simply a pattern that emerges as large numbers of autonomous individuals negotiate the challenges of daily life. The pattern is real, because human beings are physically and psychologically similar and groups of people living in proximity face roughly comparable external demands. But there is nothing of substance behind the pattern, no "there" out there beyond the observable similarity among individual behaviors.

16. For an excellent review of how cultural beliefs provide resources for interpretation, see Clifford D. Shearing \& Richard V. Ericson, Culture As Figurative Action, 42 BRIT. J. SOCIOLOGY 481 (1991). The article analyzes police culture, demonstrating how the "war stories" that veterans tell to rookies convey many of the interpretive tools that rookies will need to make sense of new situations they will confront on the street. For general background, see CONRAD P. KOTTAK, ANTHROPOLOGY 354-56 (7th ed. 1996).

17. For an introduction to the psychological processes through which people build and use stereotypes, see Su SA N T. FISKE \& SHELLEY E. TA Y LOR, SO CIA L COGNITION 96-141 (2d ed. 1991).

18. On the phenomenon of simultaneous reflection and reinforcement, see JOHN M. CONLEY \& WILLIA M M. O'BARR, J UST WORDS: LAW, LANGUAGE AND POWER (1998).

19. A Ifred K roeber, The Superorganic, 19 A M. A NTHR OPOL OGIST 163 (1917).

20. See, e.g., FREDRIK BARTH, MODELS OF SOCIAL ORGANIZATION (1966). For an historical overview, see MARVIN HARRIS, THE RISE OF A NTHROPOLOGICAL THEORY 326-34 (1968). 
$M$ any sociologists and anthropologists now take an intermediate stance. They believe that culture is more than a statistical pattern but less than and different from the all-determining superorganic. Instead, they see culture as a shared set of resources, the contents of which will vary from community to community. ${ }^{21}$ These resources are embodied in and available from such things as stereotypes and widely shared stories. When members of a society confront a concrete situation, they usually draw on cultural resources to deal with it. These resources are not determinative in the sense they tell people what to do, but they are influential in suggesting how to think about a particular issue. The fact that the resources of any particular culture are not infinite explains the regular patterns we usually see in cultural behavior. Still, this model leaves open the possibility of cultural change. ${ }^{22} \mathrm{New}$ resources may enter the cultural toolkit by diffusion from elsewhere, and others may fall into desuetude if they do not seem to work. In unusual cases, members of the culture may propose new resources that manage to catch on.

A gainst the background of this theoretical understanding, it hard to see how the law can deter the kind of misconduct that $A$ yres has uncovered. ${ }^{23}$ First, is it really misconduct in any meaningful sense for people to use familiar cultural resources? What if the individual salespeople have no discriminatory intent, and no awareness of the results that their conduct is producing? Second, even if this is misconduct, is the sum of these individual outcomes corporate misconduct? The critical interaction here is between the individual salesperson and his or her cultural environment. The corporation participates only to the extent of providing an economic motive through the commission structure. The "culture" responsible for the adverse outcomes is not that of the corporation but that of society as a whole.

A t this point, a critic might interpose a number of objections. B ecause the corporation profits from the salespersons' individual reliance on stereotypes, is it not in complicity with them? O ne might cite other examples of corporations relying on cultural stereotypes-redlining, in which banks refuse to give mortgages in certain neighborhoods, ${ }^{24}$ or the blanket denial of loans to members of minority groups ${ }^{25}$ - where the law has intervened with apparent success. In such areas, the law has refused to recognize a defense of reliance on cultural stereotypes: redlining and other discriminatory credit practices are illegal. $M$ oreover, the law has sometimes positioned itself as an agent for change in the cultural resources toolkit. The most famous example is Brown v. Board of

21. See Shearing \& E ricson, supra note 16 , at $485,500$.

22. See K OTTA K, supra note 16 , at $45-46$.

23. A fter consultation with a number of consumer law specialists, in particular D on Clifford of the U niversity of North Carolina, we have come to the conclusion that the particular behavior A yres discovered is not currently illegal, unless it somehow leads to discrimination in extending credit.

24. See Fair H ousing A ct $\S 805,42$ U.S.C. $\S 3605$ (1968) (prohibiting discrimination in residential real estate sales and financing).

25. See E qual Credit O pportunity A ct § 701, 15 U .S.C. § 1691 (1974). 
E ducation, ${ }^{26}$ where the Supreme Court acted on the view that proximity and familiarity would alter cultural perceptions of race.

In the car dealer situation, however, the prospect of a meaningful legal remedy seems remote. If this were to be characterized as an instance of corporate misconduct, what would the corporation be asked to do? A n outcomebased remedy, perhaps monitoring and adjusting prices according to race and gender, would pose insuperable administrative obstacles. In the case of redlining, the evil to be remedied is a bank's refusal to grant mortgages in defined areas with predominantly minority populations. In each transaction, the outcome is a binary choice: grant or refuse the mortgage. It is a relatively straightforward matter for the law to demand that redlining cease, and then to test compliance with its demand by monitoring outcome patterns over time. Here, however, each transaction can produce any number of outcomes: no sale, or a sale at an almost infinite range of price/option combinations. O ne might demand that dealers compile price data by race and gender of customer, but only the largest would be able to generate significant numbers of truly comparable transactions. ${ }^{27}$

It is even more difficult to imagine how an outcome-based remedy could be imposed at the level of individual salespeople. How could the law insist that individual salespeople ignore the cultural information that they use in negotiating? What would they replace it with? Would they be required to develop a conscious awareness of their stereotypes, and then introduce a correction factor? A further cautionary consideration is the law of unintended consequences. When one attempts to use the law to shape cultural behavior, the result is rarely a simple linear function. W ho could have foreseen, for example, the effect that subsidizing highways and home mortgages would have on A merican urban culture ${ }^{28}$

This may be an instance in which the law cannot lead but must sit back and wait for progressive developments in the national culture. Such developments would presumably have at least two principal components: a change in consumer awareness and behavior among the women and minorities who, according to A yres, are being taken advantage of, and a complementary change among those alleged to be taking advantage. O ne can imagine a number of agents for change other than the law. The press, for example, might take up the issue, leading to an explosion of public awareness, as well as bottom-line-driven pangs of conscience among image-conscious corporations, as has happened on issues as diverse as the environment and doing business in South A frica. The fixed-price, no-negotiation sales strategy used by Saturn dealers could suddenly become more attractive to customers and manufacturers alike. Perhaps business schools, with their growing emphasis on diversity, will effect a gradual

26. 347 U.S. 483,493 (1954).

27. A yres's testers all inquired about identical cars, identically equipped. This does not happen in the real world, however.

28. See J ames Howard K unstler, Home From Nowhere, A TLANTIC M ONTHLY, Sept. 1996, at 43. The effect was that the middle class moved to the suburbs. 
change in cultural assumptions at the executive level, which will eventually trickle down to the salespeople on the lot. In any event, we conclude, the cultural issues are too complex to be resolved by simple legal fiat.

\section{B. A rcher D aniels M idland}

If press accounts can be relied on, the A rcher Daniels M idland ("A DM ") scandal is a textbook case of the robust, superorganic view of culture. The superorganic theory of culture emerged from the classic ethnographies of the first half of this century. ${ }^{29}$ These were intensive, qualitative studies of small-scale, traditional societies in which people knew each other face-to-face and where cultural values were universally known and, it appeared, almost never questioned. In such societies, culture looked to the outside observer like a tangible force, an unyielding determinant of individual behavior. The more complicated view of culture as a set of resources emerged only as anthropologists turned the ethnographic lens on their own pluralistic societies, and then began to reassess earlier work in the light of their new understandings. ${ }^{30}$

The A D M story seems a throwback to the early days of ethnography, a kind of corporate Trobriand Islands. The outline of the story is as follows: ${ }^{31}$ U nder the leadership of chairman D wayne A ndreas, A D M grew in a generation from a regional grain company into a multi-billion-dollar multinational food products company. In 1992, M ark A. W hitacre, a fast-rising A D M executive-some said the heir apparent-approached the Federal Bureau of Investigation with allegations that ADM was involved in an international conspiracy to fix the price of lysine, an amino acid used in livestock feed. A t the FBI's request, Whitacre began to carry concealed devices to tape record incriminating conversations between A D M and its presumed competitors. In the summer of 1995, the FBI began to subpoena A D M executives and documents. The investigation ultimately resulted in criminal charges against the company. There followed a plea bargain and a $\$ 100$ million fine, massive civil litigation, the retirement of $D$ wayne Andreas, and the restructuring of ADM's corporate governance to promote independent oversight by its board of directors. In a series of a bizarre plot twists during the course of the investigation, W hitacre and other ex-

29. Ethnographies in this genre, the most famous of which is probably MARGARET MEAD, COMING OF A GE IN SAMOA (1928), have shaped the public perception of what anthropology is and what anthropologists do.

30. See, e.g., SA Lly Engle MerRy, GetTing J ustice and GetTing Even (1990) (ethnography of working class A mericans); JOHN COMAROFF \& JEAN COMAROFF, ETHNOGRAPHY AND THE HISTORICAL IMAGINATION (1992) (critical reassessment of traditional ethnographic treatment of A $\mathrm{f}$ rica).

31. The account in the text draws on the following sources: K urt Eichenwald, The Tale of the Secret Tapes, N.Y. TIM ES, N ov. 16, 1997, § 3, at 1; K urt E ichenwald, I nformant in Archer Daniels PriceFixing Case Is Indicted, N.Y. TIMES, J an. 16, 1997, at D 1; Kurt E ichenwald, A rcher D aniels Informer A dmits R ecent Deception, N.Y. TIMES, J an. 15, 1997, at D 1; K urt Eichenwald, 2 E xecutives Step D own at A rcher Daniels, N.Y. TIMES, Oct. 18, 1996, at D 1; A rcher Daniels Plans Guilty Plea, DALLAS MORNING NEWS, Oct. 15, 1996, at 1D; K urt Eichenwald, A Shareholder Rebellion, N.Y. TIMES, Oct. 19, 1995, at D 1; K urt E ichenwald, Executive Said to Describe Illegal Pay at Grain Company, N.Y. TIME S, Sept. 26, 1995, at A 1. 
ecutives were fired and then charged with setting up a scheme to defraud the company of millions of dollars by authorizing payments to nonexistent vendors controlled by the conspirators. W hitacre, who once attempted suicide and has a recent history of profound psychological problems, pleaded guilty to those charges on O ctober 9, 1997.

The picture that the press reports uniformly present is of a homogeneous corporate culture imposed from the top by the A ndreas family, many members of which have occupied high positions in the company (in fact, even after all the company's troubles, when D wayne A ndreas retired in A pril of this year, he was succeeded by his nephew, G. A llen A ndreas, Jr.). The paramount value seems to have been loyalty to $D$ wayne $A$ ndreas himself and to his vision for the company. That vision was one not only of wealth but of influence and control as well. V irtually every article about A D M contains some variation of the phrase "one of the most politically influential corporations in the country," and D wayne A ndreas is given such epithets as "one of the most powerful forces in the country in national politics for more than two decades." 32 Several recurrent anecdotes confirm the company's powerful influence: Dwayne Andreas's $\$ 25,000$ contribution to $\mathrm{R}$ ichard $\mathrm{N}$ ixon ended up in the bank account of a Watergate burglar; Bob Dole bought his Bal Harbour, Florida vacation condominium from A ndreas; and the company's self-interested promotion of ethanol, a gasoline additive made from corn has made it the "most prominent recipient of corporate welfare in U.S. history." ${ }^{33}$ Even today, former Canadian prime minister B rian Mulroney is the chairman of the ADM board and Democratic king-maker R obert Strauss is one of its members. ${ }^{34}$ D wayne A ndreas's relation to the corporation is almost always described in terms of power, and his rule often characterized as an "iron grip." 35

O rganizing a price-fixing conspiracy seems to have been an almost natural development in an autocratic, top-down corporate culture that prized influence and control above all else. In the business world, price fixing is the ultimate form of control-control over the vicissitudes of the market. It is the economic equivalent of a sailor being able to control the wind. R egardless of where in the company the scheme originated, it may have seemed like a reasonable idea. If it came from the very top, it probably struck those below as just an incremental step along the continuum of power and influence. If it originated closer to the middle, this was the kind of cultural environment in which it would have been propagated quickly, indeed enthusiastically. It was the sort of thing this company did, just a clever extension of the dominant cultural values.

The ADM culture seems to have lacked countervailing forces that might have provoked resistance. R esistance would have been an act of disloyalty to the company as well as to the family that personified it, and disloyalty is a car-

32. See, e.g., Kurt E ichenwald, Executives Said to D escribe Illegal Pay at Grain Company, N.Y . TIMES, Sep. 26, 1995, at A 1.

33. A rcher Daniels Plans G uilty Plea, D A LLA S M OR NING NEWS, O ct. 15, 1996, at 1 D.

34. See id.

35. See, e.g., K urt E ichenwald, Grain, H ogs and Videotape, N.Y. TIM ES, J uly 18, 1996, at D 1. 
dinal sin in an autocratic institution. A putative whistle-blower would have been most reluctant to seek allies, and very unlikely to find any. Moreover, disloyalty probably seemed irrational. Whatever the A ndreas family was doing, it worked. The company got bigger and richer and more powerful. A nyone contemplating resistance would have been plagued by self-doubt: Who am I to question ADM? In hindsight, it seems almost inevitable that the whistleblower turned out to be an emotionally unstable person.

G iven its relative cultural simplicity, the A D M case represents a situation in which investors and legal authorities can exert some preventive influence. At the time of the price-fixing charges, ADM was in essence a family business grown to multinational proportions. A nthropologists have long observed that small-scale societies can enjoy successful governance without formal legal structures. $^{36}$ In a society where everyone knows everyone else intimately, kinship, religious values, the fear of shame, and a sense of reciprocal obligation suffice to maintain order. In the technologically simplest societies, such as the !K ung San foraging bands of southern A frica (the "Bushmen" portrayed in The Gods M ust Be Crazy (20th Century Fox 1981)), there is no permanent authority at all. People with proven abilities step forward to deal with particular kinds of problems. The principal check on deviant behavior is the fact that there is no place to hide. Barring the deviant from participation in the support system of social life can be a brutally effective sanction in the harsh, marginal environments where foraging bands have lived in historical times. ${ }^{37}$

In the smallest of cultivation-based communities, such as A mazon villages, the "headman" is a leader of sorts, but he lacks coercive power ${ }^{38} \mathrm{H}$ is ability to lead depends upon his personal prestige, which is both intangible and ephemeral. If he were to deviate from community values, his prestige would evaporate. Moreover, even if a deviant headman retained his following, the consequences for those beyond the boundaries of the village would be minimal, given the economic and technological limits on the ability of such societies to project their influence.

B ut such arrangements work only in band or village communities. The production of surpluses and attendant population growth bring with them a need

36. See MARVIN HARRIS, PEOPLe, CUlture, NATURE 276-81 (1997) (analyzing governance in band and village societies). For a more theoretical treatment of these issues in anthropology, see J OHN L. COMAROFF \& SIM ON R OBERTS, R ULES A ND PROCESSES 3-29 (1981). For a fascinating application of similar thinking to contemporary A merica, see ROBERT ELLICK SON, ORDER WITHOUT LAW (1993). Ellickson demonstrates that, even in a modern nation-state, isolated and coherent communities (the cattle ranchers of Shasta County, California are his principal example) can and do maintain order without recourse to formal law.

37. The foraging (or, as it was formerly called, hunting-and-gathering) way of life was the exclusive human condition until the invention of agriculture about 10,000 years ago. It has persisted primarily in desert environments, as in the case of the !K ung San and the aborigines of A ustralia, and among the native peoples of the A rctic. A Ithough it is interesting to speculate about how prehistoric, small-scale societies might have been governed, we need to be cautious in using the lives of contemporary foragers who live in marginal environments to reconstruct the cultures of prehistoric bands that lived in more hospitable environments before being displaced by food producers.

38. See, e.g., DENNIS WERNER, A MAZON J OURNEY 29 (1990). 
for the more clearly defined legal and political structures we associate with the state. The subtle forces that suffice to govern a village are inadequate when anonymity replaces intimacy and surpluses tempt people to social and economic climbing. Structural controls must replace personal ones. ${ }^{39}$

In anthropological terms, ADM was a village that suddenly grew into a state without changing its governance arrangements. K inship may be enough to organize a village of 100 horticulturists, but not a nation-state or a multinational corporation. ${ }^{40}$ Patriarch and "headman" D wayne A ndreas never lost his prestige-based authority in the corporate village because he never deviated from cultural norms. On the contrary, he embodied them. The interpersonal controls that limit behavior in small-scale societies never had occasion to be invoked, and the impersonal, structural controls found in state-level societies did not exist at $A D M$.

The lesson for large and influential (that is, institutional) investors, and perhaps for the law, is not to allow kinship-based governance when a corporation grows beyond the level of an economic "village." A fter the fact, the company instituted changes designed to provide a higher level of independent scrutiny. ${ }^{41}$ These changes should have been in place long before. A llowing A DM to continue as a family autocracy, even though it appeared to be working, was akin to allowing a modern industrial state to be governed as a hereditary chiefdom.

To conclude, we cannot overemphasize that this straightforward prescription is appropriate only because the analysis of the culture itself seems so straightforward. A D M actually appears to fit a model of culture as a relatively homogeneous, top-down determinant of individual behavior. In anthropology, that model has rarely proved useful in analyzing elements of complex industrial societies (such as corporate culture, as the car dealer case indicates), and its utility in dealing even with small-scale, face-to-face societies has also been called into question. The fact that it does work here is unusual, so legal reformers should draw no general inferences about their ability to repair other dysfunctional corporate cultures by making discrete structural changes.

39. See HARRIS, supra note 36 , at 291-303 (discussing emergence of hierarchical, coercive governance).

40. See id. at 260-305 (comparing social organization and governance in pre-state and state-level societies).

41. Institutional investors had been complaining for years that the A D M board of directors lacked sufficient independence from the A ndreas family, but the company was unresponsive until the pricefixing scandal broke. See K urt E ichenwald, A Shareholder Rebellion, N.Y. TIMES, O ct. 19, 1995, at D 1. At the time of the October 1996 annual meeting, pressure from institutional shareholders caused D wayne A ndreas and his son, vice-chairman M ichael D. A ndreas, to take "leaves of absence." The same shareholders narrowly failed in an effort to change A D M 's bylaws to require a majority of truly independent directors. See K urt E ichenwald, 2 Executives Step D own at Archer Daniels, N.Y. TIMES, Oct. 18, 1996, at D 1. In M ay 1997, when a group of A D M directors settled a number of shareholder derivative actions against them, the settlement agreement included governance reforms designed to promote independent scrutiny by outside directors. See Archer Daniels D irectors Settle, N.Y. TIMES, $M$ ay $31,197, \S 1$, at 35. 


\section{Tobacco}

The tobacco case is, from a cultural perspective, the most complex of the three. R ecent news about the tobacco companies has been dominated by the proposed national settlement of the many suits brought by state attorneys general on behalf of constituents suffering from smoking-related illnesses. ${ }^{42} \mathrm{O}$ ur focus, however, has been on the sub-issue of document suppression and destruction. From the original Surgeon General's report in 1964 linking smoking and cancer until last year, the tobacco companies held to a strict party line that there was no scientific evidence that smoking caused illness. Their united front enabled them to beat back case after case brought by individual smokers. J uries invariably found that the plaintiffs were responsible for the consequences of their decisions to smoke. ${ }^{43}$

The front began to crack in the mid-1990s, in large part due to the efforts of a shadowy figure named Merrell W illiams. Described in one newspaper account as "a 56-year-old alcoholic who battles his demons with anti-depressants and weekly trips to a shrink," ${ }^{44}$ W illiams, unemployed and broke, took a job in 1987 as a document coder for a law firm defending the Brown \& Williamson tobacco company. The next year, he began to steal and copy thousands of stunningly incriminating documents, eventually getting them into the hands of anti-tobacco scientists and plaintiffs' lawyers. ${ }^{45}$ The documents revealed, among myriad other things, that B rown $\&$ W illiamson scientists and executives were studying the addictive effect of nicotine in the 1960s, withheld data from the federal government, and ordered damaging documents shipped out of the country. There is also abundant evidence, in the Brown \& Williamson documents and elsewhere, that tobacco executives and their lawyers endeavored to hide inconvenient documents behind the shield of attorney-client privilege or work product immunity by having lawyers participate in their creation, however inappropriately. In some cases, after-the-fact protection was sought, often through the facile device of shipping existing documents to outside counsel.

A Ithough W illiams has been derided by tobacco interests as a liar and thief (one B rown \& Williamson lawyer called him "my Torquemada" and said "I'Il see him in hell" ${ }^{46}$ ), his industrial espionage has radically altered the landscape of the tobacco liability litigation. Williams's revelations were followed by an admission by the chairman of the parent company of $R . J$. Reynolds that "cigarettes play a role in causing lung cancer" ${ }^{47}$ and the defection of a long-time

42. See Jill A bramson, T obacco B raced for Costly Fight, N.Y. TIMES, D ec. 15, 1997, at A 1.

43. See David Barstow, The Thief and the Third Wave, St. PetersbuRg TIMES, A pr. 6, 1997, at IA (hereinafter Barstow I); D avid Barstow, The Thief and the Third Wave, ST. PETER SBURG TIMES, A pr. 7, 1997, at $1 \mathrm{~A}$ (hereinafter Barstow II).

44. Barstow I, supra note 45 . The above account of W illiams and the B rown $\&$ W illiamson documents is based on B arstow's series.

45. Williams is apparently living off the largesse of M ississippi plaintiffs' lawyer Dickie Scruggs, who has made millions in asbestos litigation. B arstow II, supra, note 45.

46. Id.

47. Barry M eier, Chief of R.J. Reynolds Says Smoking Has Role in Cancer, N.Y. TIMES, A ug. 23, $1997, \S 1$, at 7 . 
tobacco industry medical consultant. ${ }^{48}$ The disclosure of the long-suppressed documents has become the dramatic centerpiece in the lawsuits brought by numerous state attorneys general. D ocuments recently released by a Florida trial court include a 1981 statement by a Liggett G roup lawyer that "cigarettes kill people beyond a reasonable doubt" and a 1964 memorandum from A rnold, Fortas \& Porter, Liggett's outside counsel, which raised the possibility of destroying troublesome documents. ${ }^{49}$ Florida state officials describe these as merely "the tip of the iceberg." ${ }^{50}$

D ocuments subsequently released in litigation in M innesota, Puerto R ico, and elsewhere paint an even more detailed picture of such practices as placing lawyers in non-legal executive positions in an effort to spread a cloak of privilege over business meetings, routing scientific documents through lawyers to create a colorable claim of privilege, and lawyers advising companies to destroy adverse scientific findings. ${ }^{51}$ A mong the nationally-prominent law firms charged with such abuses are Covington $\&$ Burling of Washington, D.C., and Shook, $\mathrm{H}$ ardy $\&$ B acon of $\mathrm{K}$ ansas $\mathrm{C}$ ity, both of which have been named as defendants in multiple tobacco liability suits. ${ }^{52}$

The question we take up is how this pattern of behavior might have come about. What sort of cultural environment would induce executives and their lawyers to suppress or destroy evidence and, it appears, lie about its existence? The critical factor, we believe, was a collaboration, in part deliberate and in part accidental, between business and legal cultures in defining secrecy and exalting it as a value. ${ }^{53}$

A nyone with experience in business or business law will be familiar with the lengths to which many businesses go in pursuit of secrecy for the sake of secrecy. R outine documents are stamped "confidential," meaningless electronic

48. See Lee Hancock \& Mark Curriden, Researcher's Defection Sets Stage for Court Showdown with Tobacco Industry, D A LLA S M ORNING NEWS, Jan. 4, 1998, at 11A. The consultant, Texas physician $\mathrm{G}$ ary $\mathrm{H}$ ubert, had received millions of dollars in research support and consulting fees from the industry over the past 25 years. He is now expected to testify on behalf of the state of Texas in its lawsuit against the industry, detailing how his research was manipulated and how industry lawyers abused the attorney-client privilege to suppress or destroy damaging documents. See id.; see also M ark Curriden $\&$ G eorge R odrigue, State's Tobacco Suit A ids Criminal Probe, D A L LA S M OR NIN G NEWS, O ct. 7, 1997, at $1 \mathrm{~A}$.

49. See Barry Meier, Tobacco L awyers' Papers are Made Public, N.Y. TIMES, A ug. 7, 1997, at A 18. The Florida courts have ruled that the documents are not protected by attorney-client privilege because they contain evidence that the lawyers were involved in a crime or fraud. See A merican Tobacco Co. v. Florida, 697 So. 2d 1249, 1256 (Fla. 1997)

50. See id.; see also B arry Meier, Release of Tobacco Memos Brings Lawmakers' Demand for More, N.Y. TIMES, D ec. 19, 1997, at A 32.

51. See Peter S. Canellos, Tobacco L awyers' Role: Counsel or Coverup?, B OSTON G LOBE, D ec. 28, 1997, at A 1; Peter S. Canellos, Anti-Tobacco Forces Focus on Industry A ttorneys, BOSTON GLOBE, D ec. 21, 1997, at A 1.

52. Seeid.

53. A number of people responding to our conference presentation and a subsequent newspaper article, John M. Conley \& William M. O'Barr, Tobacco's Cloak of Secrecy, RALEIGH NEWS \& O BSER VER, Jan. 4, 1998, at 20A, have suggested, "Why are you making this so complicated? They're just bad people, a bunch of crooks." This may well be true, but it begs the larger question of why so many of them congregated in the tobacco industry for more than 30 years. What was it about this industry that led to these uniquely widespread, unchallenged, and pernicious abuses? 
communications are diligently encoded, and sales personnel are warned to guard with their lives customer lists that could be gotten from a telephone book. M any business people seem to treat concern with secrecy as a badge of corporate maturity. (I ronically, these practices often coexist with a disdain for real intellectual property protection, usually driven by ignorance and a desire to save legal fees.)

For the tobacco companies, there was in addition a compelling materialist motive to pursue secrecy: survival. A pparently, for more than thirty years, tobacco executives had in their possession documents and information that could have ruined them. But what pushed these people over the edge? Experience suggests that most business people (or even politicians) do not destroy or lie about incriminating evidence; it is news when it happens. ${ }^{54}$ A nd it is certainly news when lawyers in big, rich, and prestigious firms cooperate in the effort.

The simple materialist explanation is attractive. Early on, tobacco executives saw what they had at stake and decided to take whatever measures were necessary to protect their companies and themselves. A s in most corporate environments, secrecy came easily. O nce started down that road, there was no turning back. O thers who had to be brought in on the scheme were reminded of their own economic interests. The lawyers did whatever their huge clients asked.

B ut perhaps this explanation is too simple. The cloak of secrecy extended over many ostensibly competitive companies and, presumably, large numbers of officers, directors, and employees within each one. $Y$ et until very recently, no one ever broke ranks; it took a thief to destroy the united front. A parallel question is why so many lawyers at the peak of their profession took the risks they apparently did, suspending judgment to follow their clients over a moral cliff.

A s we have already suggested, business tends to celebrate secrecy as an abstract value, and there was a compelling economic reason to pursue secrecy here. Significantly, secrecy is also a transcendent value in law and legal practice. A lawyer must protect a client confidence, even, in most cases, when the client has committed a crime. The work product doctrine allows lawyers to shield their files from the prying eyes of their adversaries. In many intellectual property contexts, the law not only permits secrecy, it requires it as a precondition to legal protection.

In the tobacco case, the mutually reinforcing effects of the two cultures may have inflated the value of secrecy exponentially. Initially, members of each culture-corporate and legal-drew on secrecy as a resource in responding to the crisis of adverse information. B ut as they did, secrecy took on a life of its own, so dominating the thinking of individual members that it became a determinant of their behavior. In the end, secrecy may have taken on such intrinsic value

54. We wrote this sentence before the M onica L ewinsky scandal erupted, but it certainly demonstrates the point. 
that corporate and legal actors ceased to question whether what they were doing was legally or morally right.

This analysis greatly complicates the task of deterrence. This is not the sort of straightforward, top-down cultural problem we encountered in the ADM case, inviting a straightforward structural remedy. How is the law to prevent the multiplicative convergence that took place here? In effect, two existing, functional cultures merged to produce a mutant hybrid in which ordinary values were distorted beyond recognition. E ven in hindsight, it is difficult to identify anything that the law could have "fixed" in either of the original cultures. In particular, there is nothing wrong with secrecy being in the resource toolkit of both the corporate and legal cultures; indeed, it needs to be there. Moreover, secrecy was already closely regulated. On the lawyers' side, the doctrines of attorney-client privilege and work product immunity have long been narrowly defined. It is abundantly clear, for example, that you cannot immunize a document simply by putting it in a lawyer's file. ${ }^{55} \mathrm{Y}$ et things that are abundantly clear seem to have been ignored in this case. A s difficult as it is to explain how this abuse might have been prevented, it is even more difficult to predict where the next of these disastrous convergences of values will occur.

\section{CONCLUSION}

A Ithough the three cases we have discussed are all nominally cases of corporate misconduct, from a cultural perspective they have little in common. The differences derive not only from the distinct facts of the three cases, but also from the distinct model of culture that is appropriate to each. These cultural differences have important implications for the attribution of blame and responsibility to the corporate entity as well as for the feasibility of a legal remedy.

The car dealer case evokes a theory of culture as epiphenomenon. That is, if we allege a corporate culture of discrimination, we are not making a statement about some robust, almost tangible force that drives individual behavior, but are merely observing a pattern in a large number of individual decisions which may have been made without reference to the corporate culture at all. Culture in this sense is effect rather than cause.

In the car dealer case, fixing responsibility for the discriminatory outcome on a corporate entity (dealer or, perhaps, manufacturer) seems unreasonable. Indeed, if there was misconduct, it is hard to categorize it as "corporate" at all. Individuals made decisions that had broadly anti-social effects. But, in doing so, they drew on cultural resources available in society as a whole that had little connection to their respective corporate environments. To the extent we attribute their behavior to some corporate culture, we mean nothing more by culture than a statistical pattern.

55. See, e.g., U pjohn Co. v. U nited States, 449 U .S. 383, 399 (1981). 
For similar reasons, the problems of remedy and deterrence seem almost insurmountable. There is no discrete flaw in the corporate culture that we can fix. The problem lies in society as a whole, and it is elusively multi-faceted. A s noted earlier, ${ }^{56}$ imposing an outcome-based remedy on a dealership would probably be unworkable. M oreover, demanding that individual salespeople renounce everyday cultural resources in making sales raises the specter of unintended consequences: W hat will they use in their place, and will the results be even worse? We conclude, with some reluctance, ${ }^{57}$ that the cultural problem is too complex to be solved by the kinds of remedies that the law has historically been able to administer, such as forbidding this behavior or requiring that.

The ADM case evokes the early days of anthropology, when culture was seen as an independent force, a powerful determinant of individual behavior. A DM did have an identifiable and relatively homogeneous corporate culture, and it came from an identifiable source, the A ndreas family. I ts dominant values of power, influence, and control were imposed from the top and passed down, quite literally, from generation to generation. A central element of the A D M culture was a highly personalized system of governance appropriate for a small-scale, kin-based community. When ADM evolved swiftly into an anonymous multinational entity, its governance model failed. There were no structural constraints to prevent the "headman" from attempting to impose his values on the world beyond his own village.

In such a case, the attribution of responsibility to the corporate culture is meaningful. There was a distinct corporate culture, and it was flawed in discrete ways. Consequently, the prospects for preventive structural reform are fairly straightforward. The law is quite capable of making and enforcing the kinds of demands ultimately made by ADM's institutional investors. In anthropological terms, they amount to an insistence that villages that seek to act as states be governed as such.

The tobacco case is the most complex of the three. It fits the contemporary anthropological theory of culture, which is far more complicated than its predecessors. Culture is seen as a collection of ideas, practices, and other resources, related yet diverse. It does not strictly determine individual behavior, but rather offers the individual a range of possibilities. The relevant resource here was secrecy. The cultures of both the industry and its lawyers did not demand secrecy in the first instance, but offered it as a highly valued possibility.

The current concept of culture also accommodates the realities of resistance and change far better than its predecessors. Certain possibilities may be dominant at any point in time, but they are always susceptible to challenge and overthrow. E ven the apparent monolith of tobacco was vulnerable, although it took

56. See supra note 27 and accompanying text.

57. Some of those in attendance at the conference commented that the discrimination A yres discovered not only is beyond the capacity of the law to solve, it is not even a problem worth worrying about. While we share their pessimism about a workable legal solution, we disagree strongly on the latter point. Surely, a supposedly efficient market producing different economic outcomes on the basis of race and gender is worth worrying about. 
a cultural deviant to expose the weakness. Finally, the contemporary view of culture emphasizes the political implications of cultural ideas and practices. Culture is not a set of quaint rituals to be preserved for ecotourists; rather, the ascendancy of particular cultural values has important consequences for life in and beyond the culture. The tobacco case amply demonstrates this point.

The tobacco case resembles A D M in that both the cigarette industry and its lawyers had well-defined cultures, and individual decisions seemed consistent with, if not driven by, a value central to each: secrecy. The unusual feature in the tobacco case is that, unlike in the ADM case, the driving value was not a bad thing in and of itself. It seems to have become pathological by virtue of the convergence of the two cultures. Because of this complicating factor, it is all but impossible to predict where such a breakdown might occur in the future. H ow are we to identify cultures with apparently adaptive values whose interaction will produce a monster? For the same reasons, no obvious program of legal reform recommends itself. The laws were in place, but they were ignored for more than thirty years. Since anthropology cannot predict when and where that will happen next, it can hardly suggest preventive changes in the law. Perhaps the best solution is for the law to deal severely with the wrongdoers it has apprehended, in the hope of creating a cultural memory that is long and deep.

This observation brings us back, finally, to the point with which we began: that anthropological analysis can be a valuable tool for those who are charged with regulating corporate behavior. To regulate corporate behavior is, after all, to regulate the behavior of the people who comprise corporations. When acting in groups, people, whether T robrianders, car dealers, or tobacco executives, constitute themselves as cultural entities and act in cultural ways. A ccordingly, if those who seek to shape corporate behavior want first to understand it, their inquiry must include a cultural perspective. A nthropology will only occasionally be able to offer answers. But in almost every case, it will offer reminders of the subtlety and complexity of human behavior, and the resulting perils of simplistic efforts to modify it. 